ljtihad: Jurnal Wacana Hukum Islam dan Kemanusiaan

Vol. 21, No. 2 (2021), pp. 197-211, doi : 10.18326/ijtihad.v21i2.197-211

\title{
Legal politics as a catalyst in forming sharia economic legal system in the Indonesia's new order and reform era
}

\author{
Andi Fariana \\ IKPLA Perbanas (Perbanas Institute) Jakarta \\ E-Mail: andi.fariana@perbanas.id \\ DOI: 10.18326/ijtihad.v21i2.197-211
}

The formation of the National Legal System is governed by legal raw materials prevailing in society (living law), including the Customary, Islamic, and Western Laws. As part of the living law, Islamic Law affects the National Legal System, especially in sharia economic law, in line with sharia economic growth in various sectors. In forming a sharia economic legal system, legal politics is significant as a catalyst that reflects the ongoing leadership pattern. This normative legal research aimed at explaining the important role of legal politics as a catalyst in forming the Sharia Economic Legal System in Indonesia, by using statute and historical approaches. The study found that various legal products at the end of the new order and the reform era indicated the existence of democratic legal politics and supported the formation of the sharia economic legal system. However, contradictions and obstacles existed, and more sharia economic law products were still needed. Therefore, a positive legal political atmosphere must be maintained by the participation of the community and religious leaders, as legal politics is strongly influenced by powers or concerns, and there will be always rejection and acceptance in the development of the sharia economic legal system due to various interests.

Pembentukan Sistem Hukum Nasional dipengaruhi oleh bahan baku hukum yang tumbuh dan hidup di dalam masyarakat (the living law). Bahan baku tersebut adalah Hukum Adat, Hukum Islam dan Hukum Barat. Sebagai salah satu dari the living law, Hukum Islam juga mewarnai Sistem Hukum Nasional, khususnya dalam bidang hukum ekonomi syariah seiring dengan pertumbuhan ekonomi syariah di berbagai sektor. Dalam proses pembentukan sistem hukum ekonomi syariah, peran politik hukum sangat penting karena politik hukum bisa menjadi katalisator yang dapat mencerminkan pola kepemimpinan yang berlangsung. Penelitian ini bertujuan mengilustrasikan peran penting politik hukum sebagai katalisator dalam pembentukan sistem Hukum Ekonomi Syariah di Indonesia. Penelitian ini merupakan penelitian hukum normatif dengan pendekatan perundang-undangan 
(statute approach) dan pendekatan historis (bistorical approach). Temuan penelitian ini adalah berbagai produk hukum yang lahir diujung era orde baru dan era reformasi mengisyaratkan adanya politik hukum yang demokratis dan sebagai bentuk dukungan yang positif bagi terbentuknya sistem hukum ekonomi syariah, walaupun ditemukan pula adanya pertentangan dan kendala serta masih perlunya berbagai produk hukum ekonomi syariah yang lebih beragam. Oleh karena itu, diperlukan kepedulian dan peran serta masyarakat serta tokoh-tokoh agama agar suasana politik hukum yang positif tetap terjaga karena politik hukum dipengaruhi oleh kekuasaan dan kekuasaan dipengaruhi oleh banyak "kekuatan" sehingga akan terus menerus terjadi tolak tarik dalam pembangunan sistem hukum ekonomi syariah karena adanya berbagai kepentingan

Keywords: legal politics; national legal system; sharia economics

\section{Introduction}

As a home for its 87, 18\% Muslim population, Indonesia has become a country with the largest Muslim population in the world and gives essential supports to sharia economic growth. The National Committee for Sharia Economics and Finance (KNEKS) data states that in a global perspective for Islamic finance, Indonesia ranks fifth after Malaysia, Bahrain, UAE, and Saudi Arabia. While for product exporters, it is in third place after Malaysia and UAE (Hidayat, 2021). Sharia economics is one of existing economic systems among some others such as capitalist or socialist. According to Asshiddiqie (cited in Habibullah, 2017, p. 4), sharia economics in Indonesia has strong foundations, namely formal shar'i and formal constitution (Habibullah, 2017, p. 4). Therefore, adequate legal instruments should support its rapid growth and development. The existence of the sharia economic legal system as part of the national legal system is necessary. It is undeniable that so far, when it comes to legal issues, public attention often revolves around issues related to the judicial system and law enforcement or bureaucratic administrative, service and organization aspects. In contrast, legal reform aspect is more important, as it will cover aspects of legislation and national legal development planning (Hartono, 1991, p. 28).

In terms of the legislation and national law development, they will be related to the existing legal raw materials living and growing in society, legal politics will process that. Meanwhile, legal politics is the implementation of policy directions from the authorities. Thus, sharia economic law products as signs that will oversee the growth and development of the sharia economy to contribute to the National Economy should be observed because 
sharia economic growth requires legal signs. At the same time, the formation of legislation cannot be separated from the growing legal politics. The role of legal politics cannot be ignored in terms of forming a legal system or legal development. Even history records that political developments from time to time, based on the period of the political system, describe the ongoing political character, whether democratic or authoritarian politics. During the Reformation era, there was a change in the character of legal politics, indicated by the birth and changes in various legal products due to solid thoughts and pressure to initiate the change from constitutional reform, the multi-dimensional crisis caused by an authoritarian political system must be changed to a democratic one (Frenki, 2021, p. 7). Likewise, a study conducted by Salam (2015, p. 124) revealed that politics and law are two things that cannot be separated and they influence each other, including the formation of the rule of law by political institutions, in the form of vital role of political powers in these institutions, including other powers that contribute to and influence the legal products created by political institutions.

The two studies above are different from this study because this study examines the role of legal politics in a specific era and traces all leadership periods to focus at the end of the New Order and during the reformation period. It also analyzes the relationship between politics and law in the formation of the legal system, and examines legal politics as a catalyst that reflects the pattern of leadership in a certain period of government. In addition, this study also aims to find out if the legal politics supported the establishment of a sharia economic legal system because politics cannot be separated from law, as legal products are political products so that by looking at legal products in the field of sharia economics, legal politics would be seen. Based on the background above, the substance of this article is divided into two sub-themes, namely Islamic law in building a national legal system, and legal politics as a catalyst. Based on the descriptions of the two sub-themes, conclusions can be formulated.

\section{Method}

This study was normative legal research with a statutory and a historical approach that aimed to generate arguments and concepts and find existing policy patterns related to the 
birth of various regulations regarding aspects of sharia economic law. The research was carried out by collecting relevant legal materials, examining the position of Islamic law in the national legal system, then conducting a legal politics study, both in the relationship between politics and law and the role of legal politics concerning legal products. After that, a search was carried out on various legal products related to Islamic law, especially in sharia economic law starting from the old order era to the present. Finally, analysis and interpretation of the relationship between legal politics and the birth of these various legal products were made.

\section{Islamic law in national legal system}

According to The Great Dictionary of Indonesian Language (KBBI 2021), catalyst (or Katalisator in the Indonesian language) means someone or something that causes changes to occur and causes new events or accelerates an event. At the same time, catalysis means the process of accelerating change. In the language dictionary, it means a substance that can speed up or slow down a reaction that is released back into shape at the end of the reaction. Catalyst in a negative sense means slowing down the reaction, while an inhibitor in a positive sense means a catalyst that speeds up the reaction. A catalyst in this paper is defined as a means or something that can contribute to accelerating or slowing down the creation of a national legal system building (in this case, the sharia economic law system). The catalyst here is legal politics as the basic policy in determining the direction and content of the law to be formed (Wahjono, 1991, p. 65).

Article 1 paragraph (3) of the 1945 Constitution after the third amendment revealed that Indonesia is a state of law and a state based on law is a matter of principle in the administration of the state. Shiddieqy (1970, p. 8) said that only the rule of law can be perfectly upright, victorious and safe (Shieddieqy, 1970, p. 8). In a country based on law, the main requirement is the existence of an independent and authoritative judiciary as an institution that enforces law and justice. Marbun (1997, p. 17) stated that the court is the root of the state of law (Marbun, 1997, p. 17). Based on these characteristics, Indonesia is based on law or as a state of law (which is very specific), namely, based on Pancasila.

A state based on Pancasila requires a law that is not passive and has tools and principles 
that regulate human relations and institutional relations so that in the end, specific rules will be realized in society (Kusumaatmadja, 2006, p. 15). Kusumaatmadja's suggested that: 1). Law is norm and institution; 2). Law is a process; 3). Law functions as a means of development. He rejected the word "a tool" in theory put forward by Roscou Pound stating law as a social engineering tool. Moreover, the word "tool" is replaced with "means" (a medium) and this word shows the dynamic nature/continues to move. His legal theory of development is following the theory put forward by Friedman (2001, pp. 7-8) who argues that the legal system consists of the following elements: (Friedman, 2001, pp. 7-8) 1). The structure of the legal system will continue to change, but the parts of the system will change at different rates, and the changes in each part will not be as fast as the others; 2). The substance is a rule which is the norms and patterns of human behavior in the system; 3). Legal culture is the human attitude towards the law and the legal system, also related to beliefs and values, thoughts and expectations. Legal culture can be a form of thought and social power that determines how the law is used, implemented, avoided, and abused.

In the Preamble of 1945 Constitution concerning the purpose of the State, a just and prosperous society is stated, and it can be interpreted that the economic issue is principle. The Indonesian economic system must be able to compete in the international world. It is well recognized that the national economy cannot be separated from the global economic system. Thus, it is hoped that the State can face global competition by maintaining and participating in fair competition. For this reason, the participation and contribution of all elements are needed to achieve the national goals. In order to guard it, it is necessary to have a legal system that reflects and pays attention to the people's participation.

One form of people's participation in the national economy is in the field of sharia economics. The development of an Islamic or sharia economy needs to be done by lifting and developing principles based on Islamic values into the National Law system. This is in line with Lawrence F. Friedman's statement that one of the important elements in the legal system is about the legal substance and in this substance is the integration of the principles of Islamic Law into the Legislative Regulations. The National Legal System is a legal system whose formation is a contribution (raw material) from three legal systems that live and grow in society, known as The Living Law, namely Customary Law, Islamic 
Law and Western Law. With his school of history, Von Savigny said that law is a historical phenomenon whose existence depends on the place and time when the law is enacted, and law is the embodiment of the soul of a nation. This historical school is reinforced by the sociological jurisprudence school, which says the importance of the living law as a living law, growing and developing in society (Rasjidi \& Thania, 2001).

Islamic law in the legal system is undeniable because it contains two main components, namely normative provisions in the al-Qur'an-Hadith and their development through interpretation and jurisprudence that has developed from time to time. As a system, Islamic law covers all fields of law, both in worship and muamalah. This muamalah field will continue to develop in line with the development of human civilization. Therefore, it can be said that Islamic law is a living law and this is why Islamic law is called the living law (Mahendra, 2021). The development of society will cause the norms of Islamic law to influence the way people think and behave directly and indirectly. The more complex the community, the more complex the legal issues and gradually the institutions that will play their role in meeting the community's needs will grow.

For this reason, it is natural that there can be tug of war between the legal awareness of the community and the will of political power, but it should be realized that the norms of Islamic law will influence or at least will try to influence the development of legal norms that will be applied to the community (Mahendra, 2021), and Islamic law (which in this case is muamalah) is legal norms that become positive raw materials for the formation and development of the sharia economic law system as part of the National Legal System. For this reason, the legal politics that is built must be positive.

\section{Legal politics as a catalyst}

Departing from the thoughts of Eugen Erhlich and strengthened by Kusumaatmaja stating that good law is law that lives in society, as well as Sidharta's opinion stating that Kusumaatmaja's development law theory requires the importance of conducive legal politics (cited in Sidharta, 2012, p. 75), so this study stated that legal politics is a catalyst for the formation of the legal system. The catalyst accelerates a process, and it is here intended to be positive legal politics. With positive raw materials (which in this case is Islamic law), 
a positive catalyst will give birth to a positive national legal system (which is the National Legal System in sharia economics).

Legal politics is a policy of state administrators that is very basic to determine the direction, form, and content of the law to be formed and determine what will be used as criteria for punishing something. So it can be interpreted that legal politics is related to the law that will apply in the future, known as the ius constituendum (Wahjono, 1991, p. 160). Legal Politics is a statement of the will of the state authorities regarding the applicable law in a particular area and regarding the direction of legal development to be built (Radhie, 1973, p. 4). Based on this definition, it can be said that legal politics are policies taken by state administrators in the field of law to be implemented in state life, both current laws and laws that will be enforced in the future. In general, these policies can be a legal configuration in the national legal system that can specifically fall into public or private law fields.

In this country, legal products are political products. This is the assumption of Mahfud (1998, p. 7) who viewed law as a formalization or crystallization of interacting and competing political wills (MD, 1998, p. 7). Currently, the House of Representatives (DPR) holds the authority to form laws. DPR will discuss the draft with the President (executive), or President can submit a draft to the DPR, so that the ratification of the drafts to be Laws is the result of a mutual agreement between the President and the DPR, and this is a form of legal politics (Fitriana, 2015, p. 6). One form of legal politics needed to achieve state goals as mandated in the Preamble of the Constitution is legal politics in the economic field. In addition, Hartono (1991, pp. 31-73) indicated that there still many economic aspects that have not been regulated, and the regulation must pay attention to justice, protection of the needs of life as well as personality and national identity in addition to paying attention to international relations and globalization in various dimensions of life (Hartono, 1991, pp. 31-73). This is where the importance of legal politics can be seen, which will be built and developed to build a National Legal System. In his dissertation, Mahfud (1998, pp. 13-15) describe that in the relationship of repulsion between law and politics, it is law that is affected by politics. It is even described in his hypothesis that the political configuration will give birth to the character of certain legal products in that country. In a country with a democratic political configuration, the legal products are responsive/populistic, while in 
a country with an authoritarian political configuration, the legal products are orthodox/ conservative/ elitist. Changes in the political configuration from authoritarian to democratic or vice versa have implications for changing the character of legal products (MD, 1998, pp. 13-15).

In connection with this study, there was a search to the implementation of Islamic law (especially legal products containing Islamic legal values in terms of substance and legal structure and culture as Friedman's theory), which is then linked to the year so that it can be assumed a form of legal political configuration taking place. In general, Islamic law is a law that lives in society and became a positive law during the Islamic empire in the archipelago, which was around the XVIII century, then there were ups and downs during the Dutch colonial period (1760-1942) but there is no form in the Japanese colonial period (1942-1945). Bismar Siregar noted that the application of Islamic law in Indonesia had occurred long before the Dutch came to Indonesia, namely around the XIV century where the Islamic kingdom of Samudera Pasai carried out the spread of Islam and this was the first time Islamic law became positive law in Indonesia. The arrival of the Dutch changed the political map so that Islamic law was applied only to Indonesian Muslims (the theory of receptio in complexu) then in 1893 another change was recorded with Snouck Hurgronje's receptie theory, which said that Islamic law was only recognized if it had been applied by local customary law (Siregar, 2007).

During the Old Order government, Islamic law became positive law during the Jakarta Charter, but subsequent developments receded along with the difficulty of transforming Islamic law into the state constitution. Several laws issued at that time, namely Law Number 22 of 1946 concerning Marriage Registration, MPR's Decree II/MPRS/1960 about GGBP, which stipulates that religious education from People's School (SR) to universities, construction of houses of worship and religious institutions, Completion of Marriage Law, Completion of Inheritance law (Safa'at, 2021). Meanwhile, during the New Order (1966-1998) it can be stated that until the early 1970s, the development of Islamic law had receded, although finally the values of Islamic law were included in the Marriage Law Number 1 of 1974, then the Law on Religious Courts Number 7 of 1989 and Presidential Instruction Number 1 of 1991 concerning the socialization of the KHI-Compilation of 
Legal politics as a catalyst in forming sharia economic legal system in the Indonesia's...(Andi Fariana)

Islamic Law (Mughits, 2008, p. 146), towards the end of the new order (in 1998) when the public insisted on ending the reign of President Soeharto, the Reformation period was marked by the leadership of President BJ Habibie, which began in 1998, followed by the reign of President Abdurrahman Wahid in 1999-2001, the reign of President Megawati in 2001-2004, the reign of President Susilo Bambang Yudoyono in 2004-2014 and the reign of President Joko Widodo in 2014-present. Each period of government certainly has its own characteristics, and during the reform period, the leadership pattern was more democratic by implementing Pancasila democracy so that the legal products were considered responsive (Marliani, 2020, p. 11).

At the end of the new order and the reformation period, the development of Islamic law underwent a significant phase of development, especially in the field of Sharia Economic Law. Several laws and regulations were issued, such as Law Number 38 of 1999 concerning Zakat, Law Number 17 of 1999 concerning the Organization of Hajj, Law Number 36 of 2006 concerning Amendments to Law Number 7 of 1989 concerning Religious Courts, as well as in the field of muamalat (sharia economics). Law Number 10 of 1998 concerning Amendments to Law Number 7 of 1992 concerning Banking which provides opportunities for the development of Sharia Banking was born (Harun, 2009, p. 164), followed by the issuance of Law Number 19 of 2008 concerning Sharia Securities, Law Number 21 of 2008 concerning Sharia Banking, Law Number 23 of 2011 concerning Zakat Management, even what is considered important is the formation of KHES (Compilation of Sharia Economic Law) as a guideline in sharia economy and its formation is coordinated by the Supreme Court and enforced based on the Regulation of the Supreme Court of the Republic of Indonesia Number 02 of 2008 (Mahkamah Agung RI, 2011).

In addition to legal products in the form of laws (both in substance and institutions), several regulation of Bank Indonesia (BI) as a tranformation of the DSN-MUI (National Sharia Council-Indonesian Ulama Council) fatwa also deserves to be noted as products of legal politics. It accommodated the need that arises because the Laws' product was inadequate in unifying the national legal system in the field of sharia economics. All legal products during the reform era (started in 1998) are positive legal products in sharia economics because they support the birth and development of various sharia businesses 
and reflect positive legal politics in building legal culture and structures. As an example is the issuance of Law Number 36 of 2006 concerning Amendments to Law Number 7 of 1989 concerning Religious Courts, which reflects the formation of legal structure and culture in terms of institutions. This law triggered changes in several important issues, not only in handling sharia economic dispute resolution but also encouraging a paradigm shift in the role of Judges and Religious Courts.

When changes to the Law on Religious Courts trigger changes in judicial institutions, the issuance of Law Number 10 of 1998 concerning Banking as an amendment to the Banking Law No. 7 of 1992 becomes an important moment because it is possible to operate banks based on sharia principles. Law Number 10 of 1998 at the end of the New Order government (entered the reform era), became a phenomenal political product because it triggered a wider sharia economic movement in Indonesia. Other Islamic economic movements were born, reflected in the forming of the National Syariah Council- the National Council of Ulama, the Islamic Economic Community (MES), the Association of Sharia Economists (IAEI), and several technical institutions both within the government and outside the government, including the establishment of various forms of sharia banking/non-banking financial institutions, and the growth of the real sector with sharia nuances even into previously unthinkable fields such as sharia hospitals, sharia tourism, sharia fashion, cosmetics, and sharia pharmacy. All signs that the legal politics developed at that time became a positive catalyst for the birth of various legal products in the field of sharia economics and triggered the birth of various policies and encouraged the growth of various other aspects that jointly contributed to sharia economic growth.

This extraordinary development in sharia business activities is still considered insufficient to be followed by the growth of required legal products due to the speedy growth of sharia economic/business activities. In contrast, the required legal products still do not meet all needs. Some examples that can be presented include sharia franchising, the applicable regulations are still dependent on the agreement made by the parties, and the general principles of the agreement are still subject to Government Regulation Number 42 of 2007 (Fariana, 2021, p. 16). Likewise, regarding the operation of sharia hospitals, it is still guided by Government Regulation Number 47 of 2021 concerning the Implementation 
of the Hospital Sector, even though DSN-MUI has issued its fatwa numbered 107/ DSN-MUI/X/2016 which can be used as a guideline. It would be better if this fatwa was transformed into a Law to be legally strong because the DSN-MUI Fatwa is not a political product in the hierarchy of Rules (Fariana, 2017, p. 100).

The rapid and widespread development requires legal products due to legal politics which will eventually become a national legal system in the field of sharia economics. But some challenges are awaiting including differences of opinion within the internal circles of Muslims who reject legislation or the materials and substances included in the legislation area. In addition, there is resistance from non-Muslims who consider Islamic law legislation into the sharia economic law system to make them seem to be second-class citizens (Iswanto, 2014, p. 281). These challenges are conceptions that are part of the input that characterizes legal politics besides the existing political power structure. These are important factors that influence and determine the legal process, namely challenges from internal Muslims and from outside Muslims and challenges that come from within the existing political power structure in which there are many interests, both because of their socio-economic background as well as their beliefs and views on life.

At the New Order era, a centralized pattern of government (a characteristic of a bureaucratic state) there were demobilization and depoliticization, intimidation of the people and cleansing of the bureaucracy from outside influences, especially political parties and religious groups. Political parties and groups' interests did not have important roles, including Muslims who did not get enough space to express themselves in their economic activities. In 1992, Bank Muamalat was established, which can be noted as an important milestone in the start of Islamic economic activity, but until the end of the New Order in 1998, Islamic banking activities did not run well. Then in the reform era with a demand of broad freedom, marked by the emergence of new political parties, including Islamic parties, the authorities are more open to the aspirations of the people and responsive to these aspirations, including Muslims' aspiration to be active in sharia economic activities (Kholis, 2013, p. 189). This responsive attitude can be seen from the formation of various legal products in the field of Islamic economics. 
So far, legal politics has an essential role in forming various legal products that will be used for the operational interests of the State, so the concept that politics is a catalyst is seen here because it is the catalyst that will boil the legal raw materials that exist and live in the community to form a national legal system. So, it can be said that the color of the national legal system will be determined by how legal politics is applied. As an example in this study, it can be seen that no matter how good Islamic law is if it is not processed correctly by legal politics, there will be no legal products derived from Islamic law. In addition, law is also often a political tool its place is in the state, thus whether the law will have more influence on politics or vice versa, this depends on the political balance, the definition of power, the evolution of political ideology. , economic, social and so on (Lev, 1990, p. xii). Therefore, it can be said that the color of legal politics is primarily determined by the color and political interests of the forces (both within formal institutions and outside formal institutions) that influence power. So, if legal politics is said to be a catalyst for the National Legal System formation, its positivity or negativity can be seen from the legal products that will become part of the national legal system. On the other hand, the main thing is that the law must pay attention to and accommodate the community's needs, especially the sense of justice, benefit and legal certainty. All must collaborate in such a way to fulfill all these aspects (Fitriana, 2015, p. 2).

\section{Conclusion}

Since 1998 particularly in the end of New Order era, the growth and development of the Islamic economy have become a milestone of the Islamic economic development in various sectors. Along with that, several laws were issued to support the legal needs. However, in accomodating the speedy development and reaching the bank/non-bank financial and the real sector, the need for various legal products is still very high. The existing legal politics largely determine the formation of a sharia economic legal system, and it is primarily determined by the existing pattern of power influenced by many factors. From that argument, then legal politics is stated as a catalyst in forming a sharia economic legal system. Even though the legal raw materials (Customary, Islamic, and Western Laws) are suitable, a positive legal system will never exist if the catalyst is negative. In contrast, good raw materials and positive catalyst will establish a positive national legal system. 
Legal politics as a catalyst in forming sharia economic legal system in the Indonesia's...(Andi Fariana)

\section{References}

Fariana, Andi. (2017) "Pengaruh Politik dalam Pembentukan Hukum di Indonesia.", Jurnal Al Ihkam Jurnal Hukum dan Pranata Sosial 1 (1). https://scholar.google. co.id > citations.

—. (2021) “Comparative Study of Law: Waralaba dalam Perspektif Perjanjian.” Perbanas Jurnal of Islamic Economics \& Business 1 (1). https://joieb.perbanas.id/index.php/Joieb.

Fitriana, Kusuma Mia. (2015) "Peranan Politik Hukum dalam Pembentukan Peraturan Perundang-undangan di Indonesia sebagai Sarana Mewujudkan tujuan Negara." Jurnal Legislasi Indonesia 12 (2). https:/ / e-jurnal.peraturan.go.id.

Frenki, F. (2021) “Politik Hukum dan Perannya dalam Pembangunan." https://media. neliti.com.

Friedman, M. Lawrence. (2001) American Law an Introductions, Second Edition (Hukum Amerika Sebuah Pengantar). 2nd ed. Jakarta: Tata Nusa.

Habibullah, Sakti Eka. (2017) "Hukum Ekonomi Syariah dalam Tatanan Hukum Nasional." Jurnal al-Mashlahah Jurnal Hukum dan Pranata Sosial 5 (09). https:// jurnal.staialhidayahbogor.ac.id.

Hartono, Sunaryati. (1991) Politik Hukum Menuju Satu Sistem Hukum Nasional. Bandung: Alumni.

Harun. (2009) "Perkembangan Hukum Islam dalam Konfigurasi Politik di Indonesia" 21 (2). https://publikasiilmiah.ums.ac.id.

Hidayat, Emir Hidayat. (2021) "Penyelesaian Sengketa Ekonomi Syariah: Makalah disampaikan dalam webinar lustrum FH Binus.”

Iswanto, Bambang. (2014) “Dimensi Politik Hukum dalam Perkembangan Ekonomi Islam di Indonesia.” Jurnal Ijtihad 14 (2). https:// doi.org/10.18326/ijtihad.v14i2.271-284. KBBI. (2021) "Lihat Juga Pada Http://Kamus.Cektkp.Com/ Lihat juga dalam Http:// www.Artikata.Com/ Definisi Katalisator dalam Kamus Indonesian to Indonesian.” http://kbbi.web.id/katalisator.

Kholis, N. (2013) "Pengaruh Politik dalam Perkembangan Praktik Ekonomi Islam di Indonesiam Perkembangan Praktik Ekonomi Islam di Indonesia.” Jurnal Millah 13 (1). https://Journal.uii.ac.id. 
Ijtihad: Jurnal Wacana Hukum Islam dan Kemanusiaan, Volume 21, No. 2, Desember 2021: 197-211

Kusumaatmadja, Mochtar. (2006) Konsep-Konsep Hukum dalam Pembangunan. Bandung: Alumni.

Lev, S. Daniel. (1990) Hukum dan Politik di Indonesia. Jakarta: LP3ES.

Mahendra, Ihza Yusril. (2021) “Kedudukan Hukum Islam dalam Sistem Hukum Nasional Filipina, Indonesia dan Malaysia: Makalah dalam Webinar Seminar Nasional Politik Hukum Islam di Indonesia."

Mahkamah Agung RI. (2011) Kompilasi Hukum Ekonomi Syariah (KHES). Revisi. Jakarta: Perpustakaan Mahkamah Agung Republik Indonesia.

Marbun, SF. (1997) “Negara Hukum dan Kekuasaan Kehakiman.” Ius Quia Lustum Law Journal of Islamic University of Indonesia Jurnal Hukum 6 (9). http://journal.uii. ac.id/index.php/IUSTUM.

Marliani, W. (2020) “Dinamika Politik dalam Perspektif Kepemimpinan di Indonesia.” Jurnal Pendidikan Politik, Hukum dan Kewarganegaraan. no. 10. https://jurnal.unsur.ac.id.

MD, Moh. Mahfud. (1998) Politik Hukum di Indonesia. Jakarta: LP3ES.

Mughits, Abdul. (2008) "Kompilasi Hukum Ekonomi Syariah (KHES) dalam Tinjauan Hukum Islam.” Jurnal Al Mawarid Edisi XVIII (Online), September, 146. https:// fis.uii.ac.id >2007/12/31.

Radhie, Teuku Mohammad. (1973) "Pembaharuan dan Politik Hukum dalam Rangka Pembangunan Nasional." Majalah Prisma, Nomor 6 Tahun II.

Rasjidi, Lili, and Ira Thania. (2001) Dasar-dasar Filsafat dan Teori Hukum. Bandung: PT. Citra Aditya Bakti.

Safa'at, Ali Muchamad. (2021) “Dinamika Hubungan Islam dan Negara dalam Perkembangan Hukum di Indonesia: Makalah dalam Webinar Seminar Nasional Politik Hukum Islam di Indonesia."

Salam, Abdus. (2015) “Pengaruh Politik dalam Pembentukan Hukum di Indonesia.” Jurnal Mazahib XIV (2). https://media.neliti.com.

Ash Shieddieqy, Hasbi. (1970) Sejarah Peradilan Islam. Jakarta: Bulan Bintang.

Sidharta, Arief Bernard. (2012) Posisi Pemikiran Teori Hukum Pembangunan dalam Konfigurasi Aliran Pemikiran Hukum dalam Mochtar Kusumaatmaja dan Teori Hukum Pembangunan. Jakarta: Epistema institute. 
Legal politics as a catalyst in forming sharia economic legal system in the Indonesia's...(Andi Fariana)

Siregar, Bismar. (2007) "Hukum Ekonomi Syariah dalam Regulasi Nasional: Makalah disampaikan dalam Seminar Nasional Kompilasi Hukum Ekonomi Syariah Kerjasama Antara Fakultas Syariah IAIN SU dengan Mahkamah Agung RI."

Wahjono, Padmo. (1991) “Menyelisik Proses Terbentuknya Perundang-undangan.” Forum Keadilan, no. 29. 
